

\section{uk feature}

\section{Cornish delight}

If Cornish pasties and farmhouse cider, rum and raisin fudge and scones piled daringly high with rhubarb and ginger preserve and clotted cream are more your thing, and you wouldn't mind heading down to the beach for a paddle or even to surf the waves after a long day in the surgery, there's always Cornwall. With 50 miles of dazzling coastline ranging from golden sands to pebbly beaches, aweinspiring cliff tops, sheltered coves and harbours embracing picturesque fishing villages, Cornwall is a paradise for those who love the sea - whether it's to swim, sail, surf, birdwatch, visit a seal sanctuary or just stroll along the shore. Further inland you might decide to track down the Beast of Bodmin Moor or admire one of the county's many castles - for example Tintagel, believed to be the birthplace of King Arthur - steeped in history spanning centuries: from Stone Age settlers to the miners of the 18th and 19th centuries through to the tourist industry of today. Weekends in Cornwall could entail a trip to Land's End, a leisurely boat ride to the Isles of Scilly or a therapeutic wander round the Eden Project taking in the lush foliage and tropical flora. At the end of the day you can retreat to

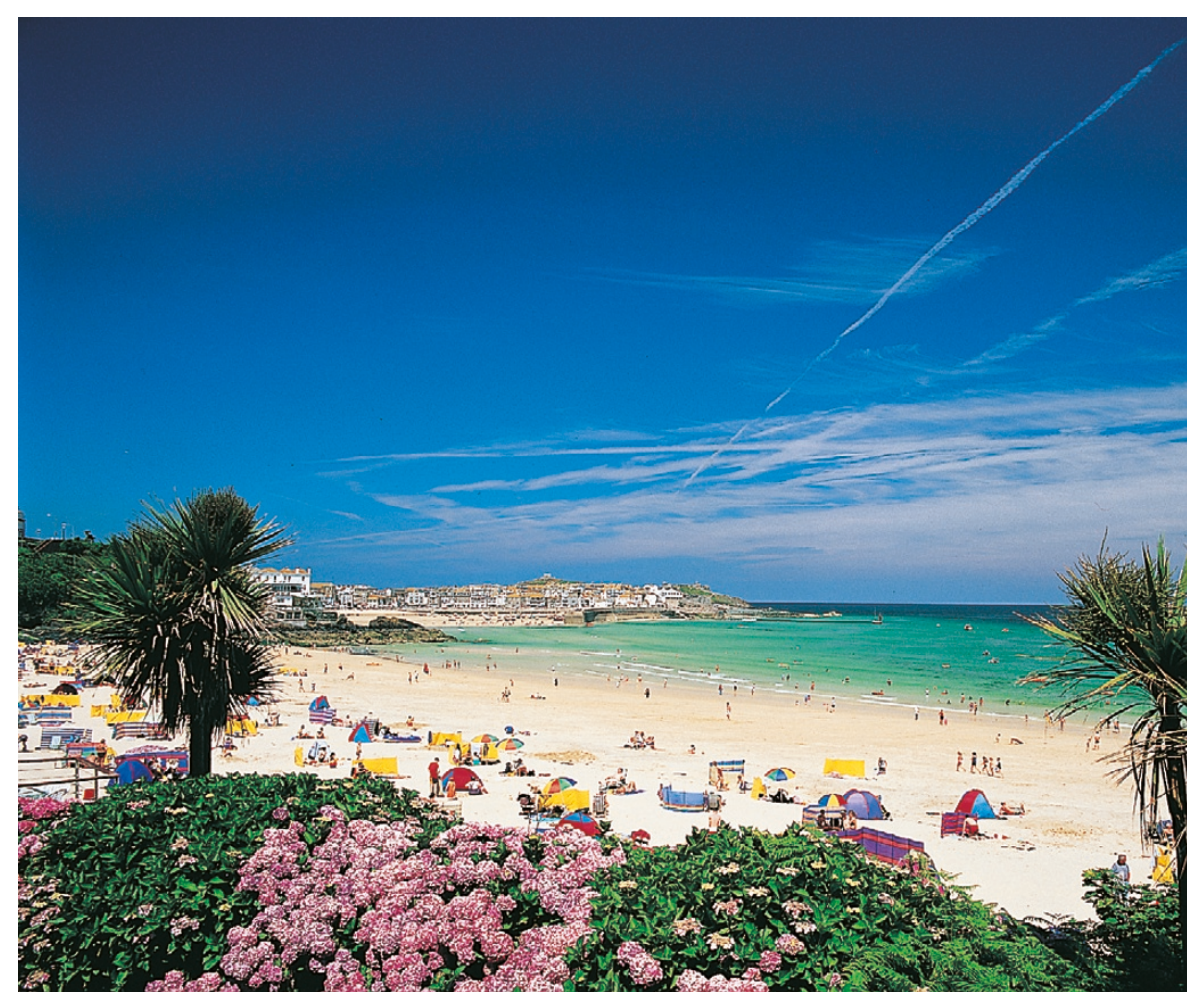

your cottage in St Ives, Mullion or Mousehole safe in the knowledge that there's always more to see the following weekend.
Useful websites

wWw.cornwalltouristboard.co.uk www.edenproject.com

\section{'With $5 \mathrm{O}$ miles of dazzling coastline Cornwall is a paradise for those who love the sea.'}

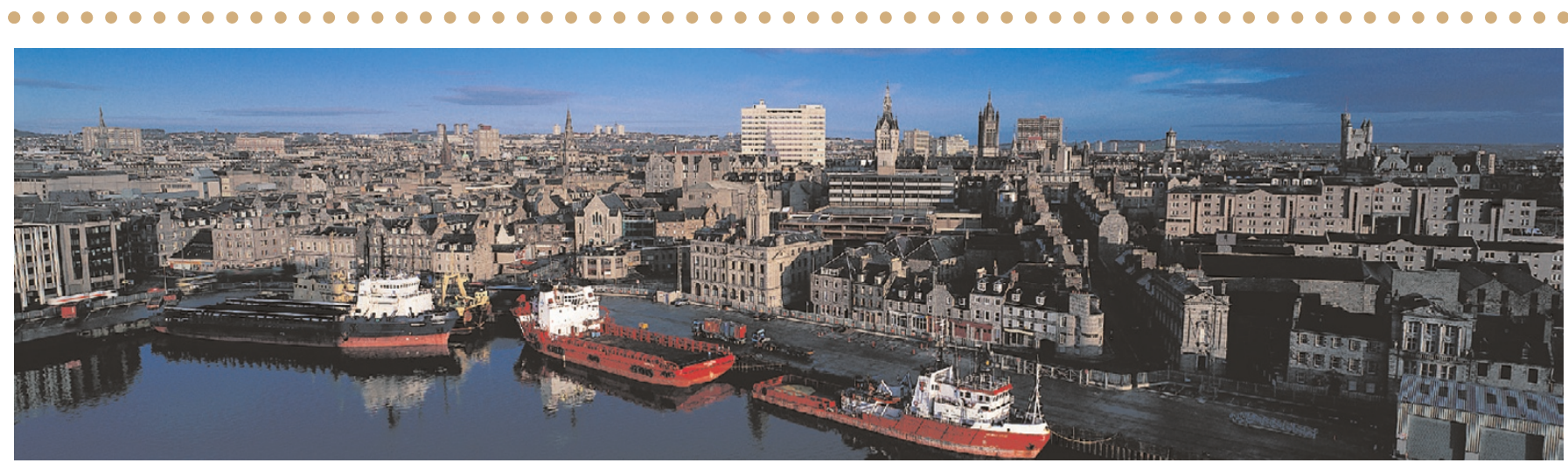

\section{Last seen in Aberdeen}

For those who prefer the John O'Groats end of our island, a less well known, dramatically beautiful region of Scotland is the 'Castle and Whisky Country' in the north-east: the Aberdeen and Grampian Highlands. Lucky enough to possess mountains and heather moors as well as coastline, Aberdeen itself is also Scotland's third largest city and an ideal base from which to explore the surrounding countryside, castles, fishing villages and malt whisky distilleries. Golfers are spoilt for choice in Aberdeenshire, but if your other half is holed up in a bunker, there are plenty of abbeys, museums, archaeological sites and stone circles to keep you busy. You could even call into Balmoral Castle for a spot of tea and shortbread with Her Majesty. In the early summer Scots take advantage of the wide open spaces to hold Highland Games, joined by highland dancers and bagpipe players galore....and if you live here you don't even need to jet off to the Alps in winter with Lecht ski resort in the vicinity. Despite all this opportunity for activity, Aberdeen and Grampian residents are probably just as happy whiling away any spare time by putting their feet up with a dram of single malt and a slice of black bun close to hand, watching the sun go down over the Cairngorms.

\section{Useful websites}

www.agtb.org and www.lecht.co.uk 